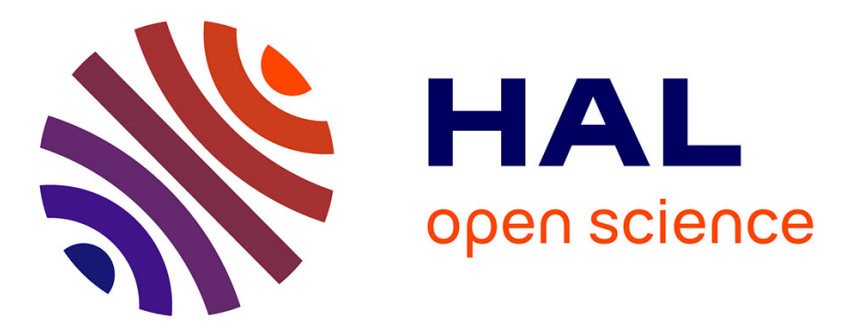

\title{
Green manure plants for remediation of soils polluted by metals and metalloids: Ecotoxicity and human bioavailability assessment
}

Yann Foucault, Thibaut Lévèque, Tiantian Xiong, Eva Schreck, Annabelle Austruy, Muhammad Shahid, Camille Dumat

\section{To cite this version:}

Yann Foucault, Thibaut Lévèque, Tiantian Xiong, Eva Schreck, Annabelle Austruy, et al.. Green manure plants for remediation of soils polluted by metals and metalloids: Ecotoxicity and human bioavailability assessment. Chemosphere, 2013, Vol. 93 ( $\mathrm{n}^{\circ}$ 7), pp. 1430-1435. 10.1016/j.chemosphere.2013.07.040 . hal-01585018

\section{HAL Id: hal-01585018 \\ https://hal.science/hal-01585018}

Submitted on 11 Sep 2017

HAL is a multi-disciplinary open access archive for the deposit and dissemination of scientific research documents, whether they are published or not. The documents may come from teaching and research institutions in France or abroad, or from public or private research centers.
L'archive ouverte pluridisciplinaire HAL, est destinée au dépôt et à la diffusion de documents scientifiques de niveau recherche, publiés ou non, émanant des établissements d'enseignement et de recherche français ou étrangers, des laboratoires publics ou privés. 


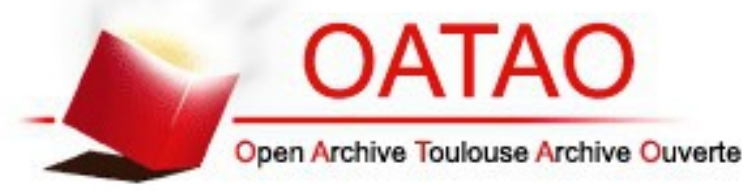

\section{Open Archive TOULOUSE Archive Ouverte (OATAO)}

OATAO is an open access repository that collects the work of Toulouse researchers and makes it freely available over the web where possible.

This is an author-deposited version published in : http://oatao.univ-toulouse.fr/ Eprints ID : 11344

To link to this article : DOI :10.1016/j.chemosphere.2013.07.040 URL : http://dx.doi.org/10.1016/j.chemosphere.2013.07.040

To cite this version : Foucault, Yann and Lévèque, Thibaut and Xiong, Tiantian and Schreck, Eva and Austruy, Annabelle and Shahid, Muhammad and Dumat, Camille Green manure plants for remediation of soils polluted by metals and metalloids: Ecotoxicity and human bioavailability assessment. (2013) Chemosphere, Vol. 93 ( $\left.\mathrm{n}^{\circ} 7\right)$. pp. 1430-1435. ISSN 0045-6535

Any correspondance concerning this service should be sent to the repository administrator: staff-oatao@,listes-diff.inp-toulouse.fr 


\title{
Technical Note
}

\section{Green manure plants for remediation of soils polluted by metals and metalloids: Ecotoxicity and human bioavailability assessment}

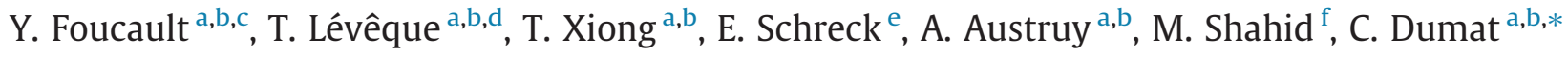 \\ a Université de Toulouse, INP-ENSAT, Avenue de l'Agrobiopôle, 31326 Castanet-Tolosan, France \\ ${ }^{\mathrm{b}}$ UMR 5245 CNRS-INP-UPS, EcoLab (Laboratoire d'écologie fonctionnelle), Avenue de l'Agrobiopôle, BP 32607, 31326 Castanet-Tolosan, France \\ 'STCM, Société de Traitements Chimiques des Métaux, 30 Avenue de Fondeyre, 31200 Toulouse, France \\ ${ }^{\mathrm{d}}$ Agence de l'Environnement et de la Maîtrise de l'Energie, 27 rue Louis Vicat, 75737 PARIS Cedex 15, France \\ ${ }^{\mathrm{e}}$ UMR 5563 CNRS/UPS/IRD/CNES GET, 14 avenue Avenue Edouard Belin, 31400 Toulouse, France \\ ${ }^{\mathrm{f}}$ Department of Environmental Sciences, COMSATS Institute of Information Technology, Vehari, Pakistan
}

H I G H L I G H T S

- Green manures plants were tested for quality restoration of soils polluted by metal(loid)s.

- Bioavailability and ecotoxicity of metal(loid)s were measured.

- Borage and mustard improve polluted soil quality.

- Phytoremediation decreases ecotoxicity and quantity of bioaccessible metal(loid)s.

Keywords:

Green manure plants

Metal(loid)s

Polluted soil

Ecotoxicity

Bioaccessibility

Phytoremediation

\begin{abstract}
A B S T R A C T
Borage, white mustard and phacelia, green manure plants currently used in agriculture to improve soil properties were cultivated for $10 \mathrm{wk}$ on various polluted soils with metal(loid) concentrations representative of urban brownfields or polluted kitchen gardens. Metal(loid) bioavailability and ecotoxicity were measured in relation to soil characteristics before and after treatment. All the plants efficiently grow on the various polluted soils. But borage and mustard only are able to modify the soil characteristics and metal(loid) impact: soil respiration increased while ecotoxicity, bioaccessible lead and total metal(loid) quantities in soils can be decreased respectively by phytostabilization and phytoextraction mechanisms. These two plants could therefore be used for urban polluted soil refunctionalization. However, plant efficiency to improve soil quality strongly depends on soil characteristics.
\end{abstract}

\section{Introduction}

In many countries, the regulation was recently reinforced to improve the management of (eco)toxicity due to chemicals uses (Schreck et al., 2013). Total quantity of lead emitted into the environment strongly decreased last years (Cecchi et al., 2008). But in the world numerous brownfields and kitchen gardens are polluted (Bacigalupo and Hale, 2012). However, the recovery of urban brownfields is required and the possibility of healthy soil gardening becomes an important issue (Foucault et al., 2012).

\footnotetext{
* Corresponding author. Address: EcoLab, INP-ENSAT, Avenue de l'Agrobiopôle, BP 32607, 31326 Castanet-Tolosan, France. Tel.: +33 05343239 03; fax: +3305 34 323901.

E-mail address: camille.dumat@ensat.fr (C. Dumat).
}

Phytoremediation techniques modify total and/or bioavailable soil metal(loid) concentrations in relation with compartmentalization and/or speciation (Butcher, 2009). Soil (micro)biology is improved (Kidd et al., 2009), large machinery and excavation equipment are not needed and soil erosion is reduced. Green manure undemanding plants, usually used in agriculture to improve soil fertility thanks to a high rhizosphere activity (Zotarelli et al., 2012) appear as good candidates for phytoremediation, as certain mustard species (Kim et al., 2010). Otherwise, in addition to the measure of total metal(loid) soil concentrations, ecotoxicity and availability measures (Denys et al., 2007) are needed. As these parameters depend on physicochemical soil properties (Foucault et al., 2013), due to their rhizosphere activity (Vamerali et al., 2010; Shahid et al., 2011, 2013), green manure plants could change metal(loid) impact. For the first time to our knowledge, green manure plants were 
therefore tested for phytoremediation on various polluted soils, with both metal(loid) human bioavailability and ecotoxicity assessment in relation with soil characteristics.

\section{Materials and methods}

\subsection{Soils sampling, preparation and characterization}

Various polluted soils were prepared from a highly contaminated sandy top soil (call T) collected from a secondary lead smelter located in Toulouse with $\mathrm{pH}=7, \mathrm{CEC}$ (cation exchange capacity) $=8.9 \mathrm{cmol}(+) \mathrm{kg}^{-1}, \mathrm{CaCO}_{3}=8 \mathrm{~g} \mathrm{~kg}^{-1}$, metal(loid) concentrations $\left(\mathrm{mg} \mathrm{kg}^{-1}\right)$ : $\mathrm{Pb} 39,800 \pm 796$, As $288 \pm 6$, Cu $286 \pm 6$, Cd $18 \pm 1, \mathrm{Zn} 294 \pm 6$ and Sb $2095 \pm 42$. Soils were cleaned of roots and visible plant materials, dried and sieved under $2 \mathrm{~mm}$. According to Leveque et al. (2013), soil T was mixed with two unpolluted loamy calcic top cambisol profiles, with metal(loid) concentrations close to the natural geochemical background and noticed $\mathrm{C} 1$, in order to prepare the metal(loid) concentrations ranges: $400 \mathrm{mg} \mathrm{Pb} \mathrm{kg}^{-1}\left(\mathrm{C}_{2}\right)$ and $825 \mathrm{mg} \mathrm{kg}^{-1}\left(\mathrm{C}_{3}\right)$. Soil 1 has a high OM (Organic Matter $) \quad$ content $\left(44.7 \mathrm{~g} \mathrm{~kg}^{-1}\right), \quad \mathrm{pH}=6.5$, $\mathrm{CEC}=12.3 \mathrm{cmol}(+) \mathrm{kg}^{-1}$ and a low $\mathrm{CaCO}_{3}$ content $\left(16.1 \mathrm{~g} \mathrm{~kg}^{-1}\right)$; while soil 2 is basic $(\mathrm{pH}=8.3)$, carbonated $\left(98 \mathrm{~g} \mathrm{~kg}^{-1}\right)$ with low OM content $\left(12.5 \mathrm{~g} \mathrm{~kg}^{-1}\right)$. Before and after treatment, CEC, OM and $\mathrm{CaCO}_{3}$ contents and $\mathrm{pH}$, were measured respectively according to NF X 31-130, ISO 10694, ISO 10693 and ISO 10390, as the total metal(loid) concentrations were determined by ICP-OES IRIS Intrepid II XXDL, after mineralization with aqua regia $\left(\mathrm{HNO}_{3}, \mathrm{HCl}\right.$, ratio $1: 3 \mathrm{v} / \mathrm{v}$ ) according to ISO 11466 . The detection limits of $\mathrm{Pb}, \mathrm{Cd}, \mathrm{Sb}$, $\mathrm{Cu}$ and $\mathrm{Zn}$ were $0.3,0.2,0.2,1.3$ and $2.2 \mu \mathrm{g} \mathrm{L}^{-1}$. The accuracy of measurements was checked using a certified reference material 141R (BCR, Brussels).

\subsection{Ecotoxicity tests}

\subsubsection{Germination tests}

For each soil condition, plants of borage (Borago officinalis), phacelia (Phacelia stala) and white mustard (Sinapis alba L.) were cultivated in pots in five replicates. Germination tests and growth assays were performed to investigate soil phytotoxicity (Ma et al., 2010). Seeds were immersed in a $10 \%$ sodium hypochloride solution for $10 \mathrm{~min}$ to ensure surface sterility (Lin and Xing, 2007) and rinsed with deionised water. Then, $200 \mathrm{~g}$ dry weight of soils were placed in plastic pots: $8 \mathrm{~cm}$ (top) in diameter and $7 \mathrm{~cm}$ in height with some drain holes on the bottom. Germination was determined by visual seedling emergence and recorded after $8 \mathrm{~d}$ in exposed seeds and controls (Vila et al., 2007). After germination recording, only three seedlings of the most uniform plants were kept in each pot to perform growth assays (Gong et al., 2001). Root and shoot lengths were measured after $17 \mathrm{~d}$ of growth. Shoot height was measured from the shoot base to the top of the longest leaf and root length was measured from the root-shoot junction to the top of the longest root (Liu et al., 2005). As described by Barrena et al. (2009), phytotoxicity was then expressed by germination index, $\mathrm{GI}=($ relative seed germination $\times E) / 100$ and relative root elongation, $\mathrm{RRE}=($ mean root length in contaminated soils $/$ mean root length with control $) \times 100$. With $\mathrm{RRE}=($ seeds germinated in contaminated soils/seeds germinated in control $) \times 100$.

\subsubsection{Daphnia magna tests on leachates}

Normalized CEN 12457-2 leaching test was applied to all soil samples. Ecotoxicity of leachates was then assessed with the water flea D. magna (less than $24 \mathrm{~h}$ old) according to ISO 6341. Four replicates were tested for each soil solution and five neonates were used in each replicate, with $10 \mathrm{~mL}$ of test solution. Organisms were fed $2 \mathrm{~h}$ before the experiment. The multiwall plate placed in the incubator at $20^{\circ} \mathrm{C}$ in darkness. The mobility of $D$. magna was recorded after 24 and $48 \mathrm{~h}$, and inhibition rate was calculated. Microorganisms' validity was verified by reference toxin $\left(\mathrm{K}_{2} \mathrm{Cr}_{2} \mathrm{O}_{7}\right)$ according to the norm specifications.

\subsection{Soil respiration measurement}

Soil respiration $\left(\mathrm{CO}_{2}\right.$ efflux) was measured in situ before and after treatment with a LICOR 6400 portable photosynthesis system (infrared gaz analyzer, IRGA) fitted with a LICOR 6000-9 soil respiration chamber (LICOR, Lincoln NE). To minimize soil surface disturbances, a $10 \mathrm{~cm}$ diameter soil PVC collar (about $81 \mathrm{~cm}^{2}$ area) was installed (1-2 cm deep) $1 \mathrm{~d}$ before the measurements, in each pot in a cleared area (Han et al., 2007). $\mathrm{CO}_{2}$ flux is computed based on a running average of change in $\mathrm{CO}_{2}$ concentration with time as $\mathrm{CO}_{2}$ refills the chamber to a described concentration above ambient concentration (Yim et al., 2002). The process is repeated through three cycles and the intermediate flux data are fit with a regression, which is then used to calculate soil respiration $\left(\mu \mathrm{mol} \mathrm{CO} \mathrm{m}^{-2} \mathrm{~s}^{-1}\right.$ ) at ambient $\mathrm{CO}_{2}$ (Ramsey et al., 2005). The average measurement taken at each pot was used to report soil respiration.

\subsection{Plant experiments}

For each experimental condition, $5 \mathrm{~kg}$ of soil were placed in pots in a greenhouse. 10 seeds of each species were sown per pot after 10 min immersion in $\mathrm{H}_{2} \mathrm{O}_{2}(10 \%)$ to ensure surface sterility (Lin and Xing, 2007). After $10 \mathrm{~d}$ of germination, only 3 seedlings of the most uniform plants were kept in each pot to perform crops assays for 10 wk (Gong et al., 2001). Roots and shoots were then separated. Samples were washed with deionised water to remove potentially surface contamination (Evangelou et al., 2007) and oven-dried $48 \mathrm{~h}$ at $40^{\circ} \mathrm{C}$. The dry weight was determined and the plant parts were grinded to homogenize particle size. Then, they were mineralised $4 \mathrm{~h}$ in a $1: 1$ mixture of $\mathrm{HNO}_{3}$ and $\mathrm{H}_{2} \mathrm{O}_{2}$ at $80^{\circ} \mathrm{C}$ (Schreck et al., 2011). Metal(loid) concentrations in plant samples were finally measured by ICP-OES (IRIS Intrepid II XXDL) The accuracy of acidic digestion and analytical procedures was checked using Virginia tobacco leaves (CTA-VTL-2, ICHTJ) as reference. All analyses were realised in triplicate.

\subsection{Evaluation of metal(loid) phytoavailability with $\mathrm{CaCl}_{2}$ extraction}

Experiments were performed according to Schreck et al. (2011).

\subsection{Lead bioaccessibility}

The in vitro test consists of two parallel three step extraction procedure and simulates the chemical processes occurring in the mouth, stomach and intestine compartments using synthetic digestive solutions included both gastric and the gastro-intestinal extractions according to physiological transit times (Denys et al., 2007). According to Caboche (2009), only the gastric phase was carried out. Lead bioaccessibility was expressed as the ratio between extracted and total concentrations.

\subsection{Statistical analysis}

All tests were performed in five replicates and the results were presented as mean standard deviation. The statistical significance of values was checked using an analysis of variance ANOVA with the Least Significant Difference Fisher post-hoc test using the Statistica 9.0 package software (StatSoft, Tulsa, OK, USA). Each effect was compared to its corresponding control (with an 
uncontaminated soil). Statistical difference was accepted when the probability of the result assuming the null hypothesis $(p)$ was less than 0.05 .

\section{Results}

\subsection{Ecotoxicity of soil samples}

The three plants grow on the polluted soils without observed phytotoxicity symptoms, butthe GI and root length of borage decreased when soil $\mathrm{Pb}$ concentration increased. However, root length was different according to the type of soil: roots were between 2 and $3 \mathrm{~cm}$ longer for soil ${ }_{2}$ than in soil ${ }_{1}$. Concerning the others species, root length decreased from 12 to $10 \mathrm{~cm}$ in soil ${ }_{1}$ and from 12.7 to $8.7 \mathrm{~cm}$ in soil $l_{2}$ for mustard; and for phacelia, from 11 to $7 \mathrm{~cm}$ and from 13.5 to $8.6 \mathrm{~cm}$ respectively in soil ${ }_{1}$ and soil $_{2}$. RRE also decreased with lead concentrations and ratios varied between $55 \%$ and $100 \%$ for the two species. Daphnia test for borage showed a higher ecotoxicity after $48 \mathrm{~h}$ than after $24 \mathrm{~h}$ of contact with the polluted soils. Mobility inhibition was comprised between $10 \%$ and $25 \%$ for soil $_{1}$ and between $15 \%$ and $33 \%$ for soil ${ }_{2}$ before the experiment. After the culture-period, a decrease was registered for both soils and final ecotoxicity varied from $7.5 \%$ to $10 \%$ for soil $1_{1}$ and from $5 \%$ to $15 \%$ for soil 2 . The same trend was observed for mustard and no influence of phacelia culture was observed on daphnia mobility.

\subsection{Metal(loid) concentrations and soil parameters before and after cultures}

Fig. 1a and b concerning borage experiments respectively for soil $_{1}$ and soil 2 , shows total soil metal(loid) concentrations reduction during plant-soil contact function of the nature and initial metal(loid) concentration. In the soil 2 , the decrease was similar for the conditions $C_{2}$ and $C_{3}$ with concentrations of lead and antimony reduced by $55-60 \%$ respectively, from $33 \%$ to $49 \%$ for Cd and more modestly for $\mathrm{Zn}$ (from $23 \%$ to $27 \%$ ) and $\mathrm{Cu}$ (from $9 \%$ to $19 \%$ ). Decrease of metal(loid) concentrations was less pronounced in soil ${ }_{1}$, except for the condition $C_{3}$. The variation of Sb was $17 \%, 21 \%$ for $\mathrm{Cd}$ and was almost zero for lead in soil ${ }_{1}-\mathrm{C}_{2}$. These values increased up to $92 \%$ for $\mathrm{Sb}, 53 \%$ for $\mathrm{Cd}$ and $42 \%$ for $\mathrm{Pb}$ in soil $\mathrm{s}_{1}-\mathrm{C}_{3}$. Except for antimony, recorded variations for soil ${ }_{1}$ were lower than those in the soil 2 . Concerning mustard, variations of metal(loid) concentrations were close to those of borage, except for lead where the registered decrease was on average twice lower (maximum was 51\% in soil ${ }_{1}$ and $44 \%$ in soil 2 ). Finally, no changes were observed with phacelia. Borage and mustard induced changes of $\mathrm{CEC}, \mathrm{pH}$, and $\mathrm{CaCO}_{3}$ in soil ${ }_{1}$. At the beginning of the experiment, differences in soil parameters were explained by the dilution step. $\mathrm{CaCO}_{3}$ content increased from 16 to 71 , from 12.5 to 31.1 and from 46 to $148.4 \mathrm{~g} \mathrm{~g}^{-1}$ respectively for $C_{1}, C_{2}$ and $C_{3}$. CEC varied from 7.8 to $10.4 \mathrm{cmol} \mathrm{kg}^{-1}$ and $\mathrm{pH}$ increased from 5.7 to 8.1 . Under mustard crop, same trends were registered and values were also within the same range.

\subsection{Metal(loid) concentrations in roots and shoots}

Table 1 presented metal(loid) concentrations in borage shoots and roots. $\mathrm{Cu}$ and $\mathrm{Zn}$ were mostly present in shoots, between 26 and $188 \mathrm{mg} \mathrm{kg}^{-1}$ and between 70 and $196 \mathrm{mg} \mathrm{kg}^{-1}$ respectively, and were not detected in roots except for soil $l_{2}-C_{3}$ with concentrations close to $2 \mathrm{mg} \mathrm{kg}^{-1}$. The same trend was recorded for $\mathrm{Cd}$ with concentrations up to $16 \mathrm{mg} \mathrm{kg}^{-1}$. Conversely, lead and antimony were up to 20 times more concentrated in the roots. $\mathrm{Cu}$ and $\mathrm{Zn}$ were principally found in mustard shoots (up to $69 \mathrm{mg} \mathrm{Cu} \mathrm{kg}^{-1}$ (a) Soil $_{1}$
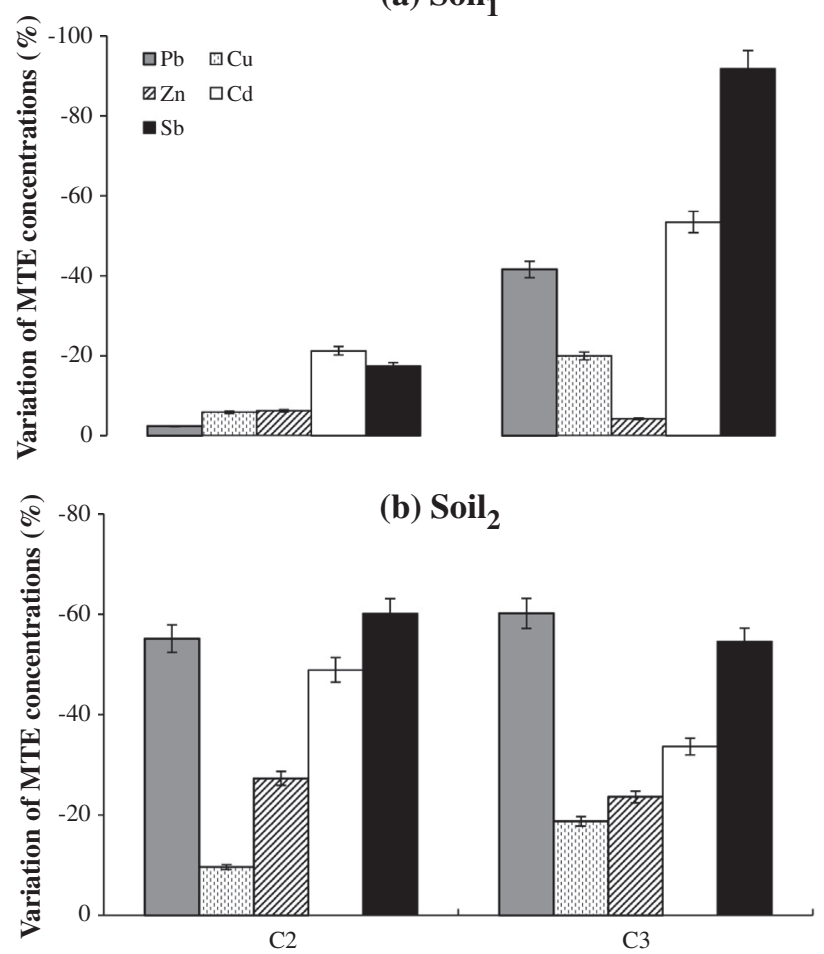

Fig. 1. Variations of metal(loid)s concentrations (in\%) in Soil ${ }_{1}$ and Soil $_{2}$ during the culture-period.

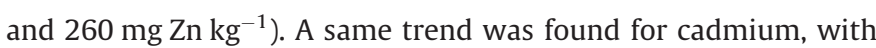
maximum concentrations in shoots of $11.1 \mathrm{mg} \mathrm{kg}^{-1}$ in soil ${ }_{1}$. Conversely to borage, lead concentrations were higher in mustard shoots: up to $1131 \mathrm{mg} \mathrm{kg}^{-1}$ in soil 2 . Only Sb followed the same trend for borage and mustard whose concentrations in roots reached 229 and $218 \mathrm{mg} \mathrm{kg}^{-1}$ for soil $_{1}$ and soil 2 respectively. Amounts of metal(loid)s recorded for phacelia both in shoots and roots were very low accordingly to low variation of metal(loid)s in soils.

\subsection{Soil respiration}

Depending of soil characteristics and initial metal(loid) concentrations, soil respiration only increased with borage (see Fig. 2) and mustard. Concerning borage, $\mathrm{CO}_{2}$ flux initially ranged from 0.84 to $1.57 \mu \mathrm{mol} \mathrm{CO} \mathrm{CO}_{2}^{-2} \mathrm{~s}^{-1}$ between soil ${ }_{1}-\mathrm{C}_{1}$ and $\mathrm{C}_{3}$, but only from 0.64 to $0.85 \mu \mathrm{mol} \mathrm{CO} \mathrm{Cm}^{-2} \mathrm{~s}^{-1}$ between soil ${ }_{2}-\mathrm{C}_{1}$ and $\mathrm{C}_{3}$. Similarly, after $10 \mathrm{wk}$ of culture, the amplitude was higher for soil $_{1}$. Moreover, soil respiration increased with metal(loid) concentrations. For soil $\left(\mu \mathrm{mol} \mathrm{CO} \mathrm{m}^{-2} \mathrm{~s}^{-1}\right)$ : $1.7\left(\mathrm{C}_{3}\right), 0.5\left(\mathrm{C}_{2}\right)$ and $0.26\left(\mathrm{C}_{1}\right)$, and for soil ${ }_{2}$ $\left(\mu \mathrm{mol} \mathrm{CO} \mathrm{m}^{-2} \mathrm{~s}^{-1}\right): 1.6\left(\mathrm{C}_{3}\right), 1.5\left(\mathrm{C}_{2}\right)$ and $1\left(\mathrm{C}_{1}\right)$.

\subsection{Metal(loid) bioavailability}

Experiments focused on lead: phytoavailability varied from 0 to 8 or $10 \mathrm{mg} \mathrm{kg}^{-1}$ respectively for soil 2 and soil ${ }_{1}$. Concerning soil ${ }_{1}$, even if the condition $C_{2}$ initially presented the highest extracted fraction $\left(66 \mathrm{mg} \mathrm{kg}^{-1}\right)$, after treatment, lead concentration was $0.3,6.7$ and $10.4 \mathrm{mg} \mathrm{kg}^{-1}$, respectively for $C_{1}, C_{2}$ and $C_{3}$. In soil ${ }_{2}$, $\mathrm{Pb}$-contents were initially below the limit detection for $\mathrm{C}_{1}$ and $C_{2}$, and reached $8.6 \mathrm{mg} \mathrm{kg}^{-1}$ for $C_{3}$. Then, concentrations for $C_{1}$ and $C_{2}$ are around $4.8 \mathrm{mg} \mathrm{kg}^{-1}$, while it was $1.8 \mathrm{mg} \mathrm{kg}^{-1}$ in $\mathrm{C}_{3} . \mathrm{Pb}$ quantities extracted under mustard were in the same range, but not detected for phacelia. 
Table 1

Metal(loid)s concentrations in shoots and roots ( $\left.\mathrm{mg} \mathrm{kg}^{-1} \mathrm{DW}\right)$ : (a) borage; (b) mustard. Values are given as mean of five replicates with three seedlings each. *DL: Detection Limit $\left(=0.1 \mathrm{mg} \mathrm{kg}^{-1}\right.$ )

\begin{tabular}{|c|c|c|c|c|c|c|c|c|c|c|}
\hline & \multicolumn{2}{|l|}{$\mathrm{Pb}$} & \multicolumn{2}{|l|}{$\mathrm{Cu}$} & \multicolumn{2}{|l|}{$\mathrm{Zn}$} & \multicolumn{2}{|l|}{$\mathrm{Cd}$} & \multicolumn{2}{|l|}{$\mathrm{Sb}$} \\
\hline & Sh. & Ro. & Sh. & Ro. & Sh. & Ro. & Sh. & Ro. & Sh. & Ro. \\
\hline \multicolumn{11}{|l|}{$1 a$} \\
\hline Soil $_{1}-C_{1}$ & 1.2 & 17.1 & 188 & $<\mathrm{DL}^{*}$ & 196 & $<\mathrm{DL}$ & $<\mathrm{DL}$ & 0.5 & $<\mathrm{DL}$ & $<\mathrm{DL}$ \\
\hline Soil $_{1}-C_{2}$ & 239 & 210.3 & 71.8 & $<\mathrm{DL}$ & 152.9 & $<\mathrm{DL}$ & 16.2 & $<\mathrm{DL}$ & 12.6 & 1.8 \\
\hline Soil $_{1}-C_{3}$ & 160.5 & 589.9 & 49.0 & $<\mathrm{DL}$ & 88.5 & $<\mathrm{DL}$ & 2.0 & 0.3 & 10.4 & 91.5 \\
\hline Soil $_{2}-C_{1}$ & 0.9 & 9.9 & 99.5 & $<\mathrm{DL}$ & 102.1 & $<\mathrm{DL}$ & $<\mathrm{DL}$ & $<\mathrm{DL}$ & $<\mathrm{DL}$ & $<\mathrm{DL}$ \\
\hline Soil $_{2}-C_{2}$ & 111.6 & 463.7 & 56.2 & $<\mathrm{DL}$ & 84.2 & $<\mathrm{DL}$ & 1.4 & $<\mathrm{DL}$ & 7.9 & 40.3 \\
\hline Soil $_{2}-C_{3}$ & 90.0 & 936.8 & 26.3 & 2.0 & 69.9 & 1.9 & 2.8 & 0.6 & 6.1 & 139 \\
\hline \multicolumn{11}{|l|}{$1 b$} \\
\hline Soil $_{1}-C_{1}$ & 1.3 & $<\mathrm{DL}$ & 69.0 & $<\mathrm{DL}$ & 122.9 & $<\mathrm{DL}$ & 0.9 & $<\mathrm{DL}$ & 7.3 & $<\mathrm{DL}$ \\
\hline Soil $_{1}-C_{2}$ & 253.0 & 2.6 & 31.9 & $<\mathrm{DL}$ & 165.4 & $<\mathrm{DL}$ & 5.5 & $<\mathrm{DL}$ & 18.9 & 4.4 \\
\hline Soil $_{1}-C_{3}$ & 250.4 & 5.9 & 12.7 & 2.2 & 260.3 & 9.6 & 11.1 & $<\mathrm{DL}$ & 12.1 & 229.3 \\
\hline Soil $_{2}-C_{1}$ & 15.3 & $<\mathrm{DL}$ & 54.4 & $<\mathrm{DL}$ & 78.7 & $<\mathrm{DL}$ & $<\mathrm{DL}$ & $<\mathrm{DL}$ & 17.1 & $<\mathrm{DL}$ \\
\hline Soil $_{2}-\mathrm{C}_{2}$ & 89.6 & 20.4 & 18.4 & $<\mathrm{DL}$ & 61.4 & $<\mathrm{DL}$ & 1.9 & $<\mathrm{DL}$ & 5.8 & 12.2 \\
\hline Soil $_{2}-C_{3}$ & 1131 & 363.6 & 58.8 & 3.5 & 91.1 & 4.5 & 3.3 & 1.1 & 79.3 & 218.5 \\
\hline
\end{tabular}

Amounts potentially accessible for human were higher than those available for plants. In the soil $1_{1}$, lead bioaccessibility was initially $39 \%, 63 \%$ and $35 \%$ respectively for $C_{1}, C_{2}$ and $C_{3}$. These ratios increased after treatment with borage to reach $46 \%, 92 \%$ and $75 \%$ respectively for $C_{1}, C_{2}$ and $C_{3}$. A linear trend was observed for the soil $l_{2}$. Lead bioaccessibility increased with soil concentration: from $8 \%$ to $15 \%\left(C_{1}\right), 27 \%$ to $50 \%\left(C_{2}\right)$ and $54 \%$ to $98 \%\left(C_{3}\right)$. However, when results are expressed as quantities, taking into account the modification of lead concentrations in soils, two behaviours were distinguished in function of soil nature. For soil $1_{1}$, the fraction of extracted lead grown with the treatment: from 251 to $359 \mathrm{mg} \mathrm{kg}^{-1}$ $\left(C_{2}\right)$ and from 291 to $362 \mathrm{mg} \mathrm{kg}^{-1}\left(C_{3}\right)$; conversely, for soil 2 bioaccessible fraction decreased from 110 to $89 \mathrm{mg} \mathrm{kg}^{-1}\left(\mathrm{C}_{2}\right)$ and from 444 to $323 \mathrm{mg} \mathrm{kg}^{-1}\left(\mathrm{C}_{3}\right)$.

\section{Discussion}

\subsection{Improvement of soil quality by ecological engineering}

Borage, mustard and phacelia were able to grow on various polluted soils. A trend for germination reduction was however observed as roots are directly in contact with pollutants (Schreck et al., 2011). Root length was influenced by lead concentration $\left(R^{2}=0.56\right.$ and 0.59 for soil $_{1}$ and soil 2 respectively), as RRE was too $\left(R^{2}\right.$-soil $1=0.74 ; R^{2}$-soil $\left.2=0.62\right)$. Soil characteristics also affected root length as showed by correlations: (i) in the soil ${ }_{1}$, $R^{2}=0.73$ for $\mathrm{pH}$ and $\mathrm{OM}$ content and 0.63 for CEC; in soil , $R^{2}=0.83,0.66$ and 0.69 with $\mathrm{pH}, \mathrm{OM}$ and $\mathrm{CaCO}_{3}$ content respectively. Root toxicity was lower in soil 2 because, as noted by Birkefeld et al. (2007), lead oxide particles incubated in calcareous soil can be covered by a crust of lead carbonate. Soil respiration significantly increased after phytoremediation, certainly in relation with both changes of abiotic (Han et al., 2007) and biotic factors as microbial activity.

\subsection{Evolution of environmental and sanitary risks}

In soil 2 , the concentration of phytoavailable lead is related to the soil concentration $\left(R^{2}=0.95\right.$ and 0.94 at 0 and 10 wk respectively). Moreover, as for soil respiration and root toxicity, $\mathrm{CaCO}_{3}$ amount is influent: $R^{2}$-soil ${ }_{1}=0.89$ and $R^{2}$-soil ${ }_{2}=0.95$ at the end of experiment. Soil properties can strongly modify metal bioavailability (Kidd et al., 2009). Soil ${ }_{1}$ showed an $\mathrm{CaCO}_{3}$ content increase and a more basic pH which can lead to a reduction of metal(loid) availability. Lead bioaccessibility (in\%) increased during the culture-period and was statistically correlated with total lead-concentrations (a) Soil 1

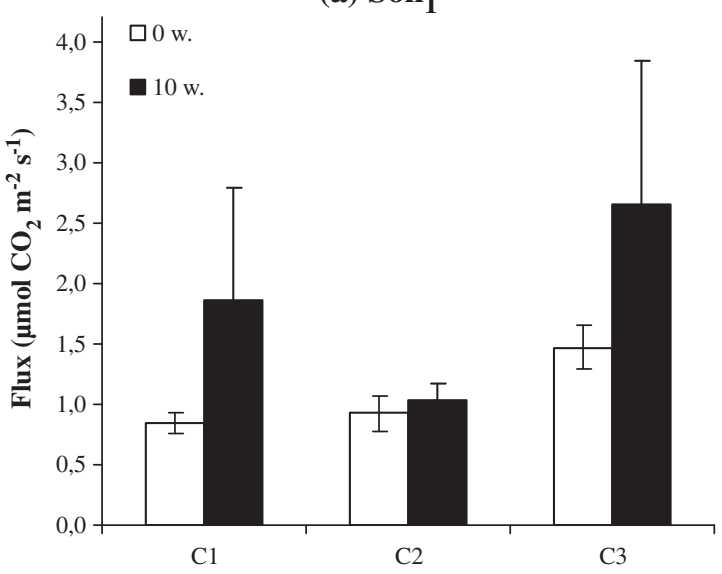

(b) Soil $_{2}$

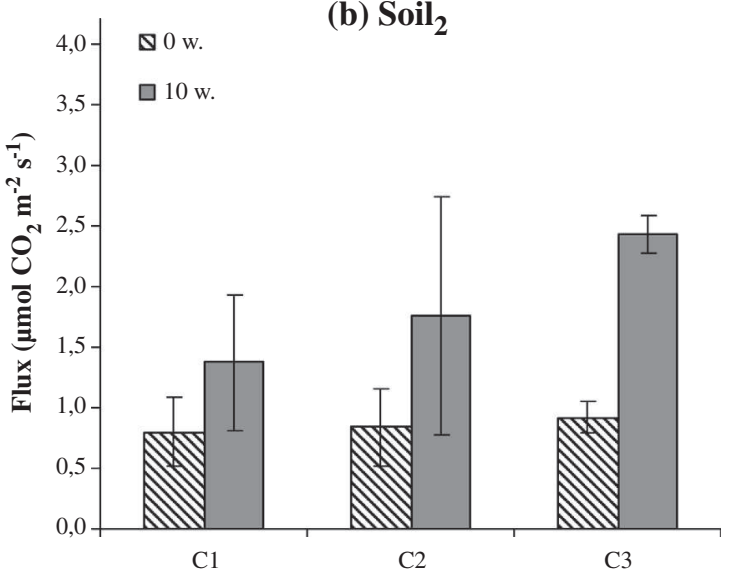

Fig. 2. Comparison of mean soil respiration rates between the beginning and the end of the experimentation for soil $1_{1}$ (a) and soil 2 (b) (in $\mu \mathrm{molCO}_{2} \mathrm{~m}^{-2} \mathrm{~s}^{-1}$ ).

$\left(R^{2}\right.$-soil $1=0.61$ and 0.95 at 0 and $10 \mathrm{wk}$ respectively; $R^{2}$-soil ${ }_{2}=0.75$ initially and 0.98 after treatment), and accordingly to Caboche (2009), with the soil characteristics: $\mathrm{pH}$ and CEC for soil ${ }_{1}$; carbonate and OM content for soil 2 . However, a lower lead quantity was bioaccessible after $10 \mathrm{wk}$ in soil ${ }_{2}$ conversely to soil $_{1}$. Moreover, soil ecotoxicity measured by sensitive daphnia test was reduced by the treatment, certainly due to rhizosphere activity.

\subsection{Suitability of green manure crops for ecological restoration of} polluted soils

Metal(loid) compartmentalisation in the plants depend both on pollutant and plant type: copper and zinc were mainly concentrated in shoots; lead and antimony were mainly concentrated in roots of borage but in shoots of mustards. According to, bio-concentration and translocation factors are respectively defined as BCF (Bio-Concentration Factor) $=\left(Q_{2}+Q_{3}\right) / Q_{1}$ and TF (Translocation Factor) $=Q_{3} / Q_{2}$; where $Q_{1}, Q_{2}, Q_{3}$ are average metal(loid) quantities (in $\mathrm{mg} \mathrm{kg}^{-1}$ ) respectively in soil, roots and shoots. BCF $>1$ indicates that the plants accumulate the pollutants and $\mathrm{BCF}<1$ indicates excluder plants (Arshad et al., 2008). Accordingly to Evangelou et al. (2007), using $\mathrm{PbNO}_{3}$ spiked soils, calculated BCF for borage was below 1 for $\mathrm{Pb}$ and $\mathrm{Sb}$. BCF was far above 1 for $\mathrm{Cu}$ and $\mathrm{Zn}$ (and $\mathrm{Cd}$ in a lesser extent) (Table 2), which are essential elements for plants (Zheng et al., 2011). TF calculated for borage were below 1 for $\mathrm{Pb}, \mathrm{Sb}$ and $\mathrm{Cd}$ (except for soil $\mathrm{l}_{1}-\mathrm{C}_{2}$ ) and above 1 for $\mathrm{Cu}$ and $\mathrm{Zn}$. Borage stabilises lead and antimony into its roots (McGrath and Zhao, 2003). Zou et al. (2011) showed that metal(loid)s are unevenly distributed in roots, where different root tissues act as 
Table 2

Bioaccumulation factors (BCF) and translocation factors (TF) calculated for (a) borage; (b) mustard.

\begin{tabular}{|c|c|c|c|c|c|c|c|c|c|c|}
\hline & \multicolumn{2}{|l|}{$\mathrm{Pb}$} & \multicolumn{2}{|l|}{$\mathrm{Cu}$} & \multicolumn{2}{|l|}{$\mathrm{Zn}$} & \multicolumn{2}{|l|}{$\mathrm{Cd}$} & \multicolumn{2}{|l|}{$\mathrm{Sb}$} \\
\hline & $\mathrm{BCF}$ & $\mathrm{TF}$ & $\mathrm{BCF}$ & $\mathrm{TF}$ & $\mathrm{BCF}$ & $\mathrm{TF}$ & $\mathrm{BCF}$ & $\mathrm{TF}$ & $\mathrm{BCF}$ & $\mathrm{TF}$ \\
\hline \multicolumn{11}{|l|}{$2 a$} \\
\hline Soil $_{1-C 1}$ & 1.0 & 0.1 & 10 & $>1884$ & 3.7 & $>1962$ & 0.6 & 0.2 & 0.1 & $<0.5$ \\
\hline Soil $_{1}-C_{2}$ & 0.4 & 0.2 & 3.7 & $>718$ & 2.1 & $>1528$ & 0.6 & 17 & 0.2 & 0.2 \\
\hline Soil $_{1}-C_{3}$ & 0.4 & 0.3 & 2.1 & $>489$ & 1.2 & $>885$ & 0.5 & 6.7 & 0.1 & 0.1 \\
\hline Soil $_{2}-C_{1}$ & 0.9 & 0.1 & 6.0 & $>994$ & 2.9 & $>1020$ & 1.0 & 1.5 & 0.1 & $<1$ \\
\hline $\mathrm{Soil}_{2}-\mathrm{C}_{2}$ & 0.4 & 0.2 & 1.8 & $>562$ & 1.4 & $>842$ & 0.6 & 13 & 0.6 & 0.3 \\
\hline Soil $_{2}-C_{3}$ & 0.2 & 0.1 & 0.8 & 13 & 0.7 & 37 & 0.7 & 4.6 & 0.5 & 0.1 \\
\hline \multicolumn{11}{|l|}{$2 b$} \\
\hline Soill $_{1}-C_{1}$ & 0.1 & $>13$ & 3.9 & $>690$ & 2.3 & $>1228$ & 1 & $>8.9$ & 2.9 & $>73$ \\
\hline Soil $_{1}-C_{2}$ & 0.2 & 96 & 1.7 & $>319$ & 2.3 & $>1653$ & 2.6 & $>54$ & 0.3 & 4.3 \\
\hline Soil $_{1}-C_{3}$ & 0.1 & 423 & 0.6 & $>5.7$ & 3.7 & 27 & 2.6 & $>111$ & 1.0 & $<0.1$ \\
\hline Soil $_{2}-C_{1}$ & 1.4 & $>153$ & 3.3 & $>544$ & 2.2 & $>786$ & 0.2 & $>1.0$ & 6.9 & $>1701$ \\
\hline $\mathrm{Soill}_{2}-\mathrm{C}_{2}$ & 0.2 & 7.2 & 0.6 & $>184$ & 1.1 & $>614$ & 0.9 & $>19$ & 0.2 & 0.5 \\
\hline $\mathrm{Soil}_{2}-\mathrm{C}_{3}$ & 0.3 & 3.1 & 1.8 & 16.8 & 1.0 & 20 & 0.8 & 2.9 & 0.9 & 0.4 \\
\hline
\end{tabular}

barriers to apoplastic and symplastic transport, thereby restricting transport to the shoots. Borage extracts and translocates $\mathrm{Cu}$ and $\mathrm{Zn}$ and could therefore be used for remediation of polluted vineyards (Banas et al., 2010). Calculated TF confirmed that mustard was relevant for phytoextraction (Bareen and Tahira, 2010). Finally, for all the performed experiments, the soil-plant metal(loid) transfer was influenced by the soil type, as metal(loid) availability may change according to the interactions with the soil matrix (Niemeyer et al., 2012; Shahid et al., 2012).

\section{Conclusions and perspectives}

Unlike to phacelia, borage and mustard can improve soil respiration, reduce total and bioaccessible metal(loid) quantities and their ecotoxicity. For lead and antimony, contrasted mechanisms were developed: phytoextraction with storage in shoots and phytostabilization with storage in roots respectively for mustard and borage. Thanks to these treatments, metal(loid)s entering in the food chain via water, wind erosion and re-flying can be reduced and a global analysis of the remediation techniques is performed. Further, as borage plants are not perennial, they should be harvested to avoid the release of metal(loid)s in soil, and treated in a waste treatment unit. Moreover, a better understanding of the complex interactions between plants and rhizosphere microorganisms is required to improve the treatment efficiency.

\section{Acknowledgements}

ANRT (National Agency for Research and Technology) and STCM (Metal Chemical Treatments Society) are acknowledged for their financial support and technical help. This work has received support from the National Research Agency under reference ANR-120011-VBDU and from Ademe, Dimension projet.

\section{References}

Arshad, M., Silvestre, J., Pinelli, E., Kellerhoff, J., Kaemmerer, M., Tarigo, A., Shahid M., Guiresse, M., Pradère, P., Dumat, C., 2008. A field study of lead phytoextraction by various scented Pelargonium cultivars. Chemosphere 71 2187-2192.

Bacigalupo, C. Hale, B., 2012. Human health risks of $\mathrm{Pb}$ and As exposure via consumption of home garden vegetables and incidental soil and dust ingestion: a probabilistic screening tool. Sci. Total Environ. 432, 27-38.

Banas, D., Marin, B., Skraber, S., Chopin, E.I.B., Zanella, A., 2010. Copper mobilization affected by weather conditions in a stormwater detention system receiving runoff waters from vineyard soils (Champagne, France). Environ. Pollut. 158, $476-482$.
Bareen, F., Tahira, S.A., 2010. Efficiency of seven cultivated plant species for phytoextraction of toxic metals from tannery effluent contaminated soil using EDTA. Soil Sediment. Contam. 19, 160-173.

Barrena, R., Casals, E., Colón, J., Font, X., Sánchez, A., Puntes, V., 2009. Evaluation of the ecotoxicity of model nanoparticles. Chemosphere 75, 850-857.

Birkefeld, A., Schulin, R., Nowack, B., 2007. In situ transformations of fine lead oxide particles in different soils. Environ. Pollut. 145, 554-561.

Butcher, D.J., 2009. Phytoremediation of lead in soil: recent applications and future prospects. Appl. Spectrosc. Rev. 44, 123-139.

Caboche, J., 2009. Validation d'un Test de Mesure de Bioaccessibilité - Application à 4 Eléments Traces Métalliques dans les Sols: As, Cd, Pb et Sb. Ph.D Thesis, Institut National Polytechnique de Lorraine (INPL), Nancy.

Cecchi, M., Dumat, C., Alric, A., Felix-Faure, B., Pradere, P., Guiresse, M., 2008. Multimetal contamination of a calcic cambisol by fallout from a lead-recycling plant. Geoderma 144, 287-298.

Denys, S., Caboche, J., Tack, K., Delalain, P., 2007. Bioaccessibility of lead in high carbonate soils. J. Environ. Sci. Health, Part A 42, 1331-1339.

Evangelou, M.W.H., Kutschinski-Klöss, S., Ebel, M., Schaeffer, A., 2007. Potential of Borago officinalis, Sinapis alba L. and Phacelia boratus for phytoextraction of Cd and $\mathrm{Pb}$ from soil. Water, Air, Soil Pollut. 182, 407-416.

Foucault, Y., Schreck, E., Levêque, T., Pradère, P., Dumat, C., 2012. Toward rational management of excavated soil contaminated by metal trace elements. Environ. Risk Health 11, 61-66.

Foucault, Y., Durand, M.J., Tack, K., Schreck, E., Geret, F., Leveque, T., Pradere, P., Goix, S. Dumat, C., 2013. Use of ecotoxicity tests and ecoscores to improve the management of polluted soils: case of a secondary lead smelter plant. J. Hazard. Mater. 246-247, 291-299.

Gong, B., Wilke, M., Strozzi, E., Fleischmann, S., 2001. Evaluation and refinement of a continuous seed germination and early seedling growth test for the use in the ecotoxicological assessment of soils. Chemosphere 44, 491500.

Han, G., Zhou, G., Xu, Z., Yang, Y., Liu, J., Shi, K., 2007. Biotic and abiotic factors controlling the spatial and temporal variation of soil respiration in an agricultural ecosystem. Soil Biol. Biochem. 39, 418-425.

Kidd, P., Barceló, J., Bernal, M.P., Navari-Izzo, F., Poschenrieder, C., Shilev, S., Clemente, R., Monterroso, C., 2009. Trace elements behaviour at the root-soil interface: implications in phytoremediation. Environ. Exp. Bot. 67, 243259.

Kim, K.R., Owens, G., Kwon, S.I., 2010. Influence of Indian mustard (Brassica juncea) on rhizosphere soil solution chemistry in long-term contaminated soils: a rhizobox study. J. Environ. Sci. 22, 98-105.

Leveque, T., Capowiez, Y., Schreck, E., Mazzia, C., Foucault, Y., Austruy, A., Auffan, M., Dumat, C., 2013. Assessing ecotoxicity and uptake of metals and metalloids in relation to two different earthworm species. Environ. Pollut. $179,232-241$

Lin, D., Xing, B., 2007. Phytotoxicity of nanoparticles: inhibition of seed germination and root growth. Environ. Pollut. 150, 243-250.

Liu, X., Zhang, S., Shan, X., Zhu, Y.G., 2005. Toxicity of arsenate and arsenite on germination, seedling growth and amylolytic activity of wheat. Chemosphere $61,293-301$.

Ma, X., Geiser-Lee, J., Deng, Y., Kolmakov, A., 2010. Interactions between engineered nanoparticles (ENPs) and plants: phytotoxicity, uptake and accumulation. Sci. Total Environ. 16, 3053-3061.

Niemeyer, J.C., Lolata, G.B., de Carvalho, G.M., Da Silva, E.M., Sousa, J.P., Nogueira, M.A., 2012. Microbial indicators of soil health as tools for ecological risk assessment of a metal contaminated site in Brazil. Appl. Soil Ecol. 59, 96105.

Ramsey, P.W., Rillig, M.C., Feris, K.P., Moore, J.N., Gannon, J.E., 2005. Mine waste contamination limits soil respiration rates: a case study using quantile regression. Soil Biol. Biochem. 37, 1177-1183.

Schreck, E., Foucault, Y., Geret, F., Pradère, P., Dumat, C., 2011. Influence of soil ageing on bioavailability and ecotoxicity of lead carried by process waste metallic ultrafine particles. Chemosphere 85, 1555-1562.

Schreck, E., Laplanche, C., Le Guédard, M., Bessoule, J.J., Austruy, A., Xiong, T., Foucault, Y., Dumat, C., 2013. Influence of fine process particles enriched with metals and metalloids on Lactuca sativa L. leaf fatty acid composition following air and/or soil-plant field exposure. Environ. Pollut. 179, 242249.

Shahid, M., Pinelli, E., Pourrut, B., Silvestre, J., Dumat, C., 2011. Lead-induced genotoxicity to Vicia faba L. roots in relation with metal cell uptake and initial speciation. Ecotoxicol. Environ. Saf. 74, 78-84.

Shahid, M., Pinelli, E., Dumat, C., 2012. Review of Pb availability and toxicity to plants in relation with metal speciation: role of synthetic and natural organic ligands. J. Hazard. Mater. 219-220, 1-12.

Shahid, M., Xiong, T., Masood, N., Leveque, T., Quenea, K., Austruy, A., Foucault, Y., Dumat, C., 2013. Influence of plant species and phosphorus amendments on metal speciation and bioavailability in a smelter impacted soil: a case study of food chain contamination. J. S. S.. http://dx.doi.org/10.1007/s11368-013-07458.

Vila, M., Mehier, S., Lorber-Pascal, S., Laurent, F., 2007. Phytotoxicity to and uptake of RDX by rice. Environ. Pollut. 145, 813-817.

Yim, M.H., Joo, S.J., Nakane, K., 2002. Comparison of field methods for measuring soil respiration: a static alkali absorption method and two dynamic closed chamber methods. Forest Ecol. Manage 170, 189-197. 
Zheng, F., Ali, S., Zhang, H., Ouyang, Y., Qiu, B., Wu, F., Zhang, G., 2011. The influence of $\mathrm{pH}$ and organic matter content in paddy soil on heavy metal availability and their uptake by rice plants. Environ. Pollut. 159, 84-91.

Zotarelli, L., Zatorre, N.P., Boddey, R.M., Urquiaga, S., Jantalia, C.P., Franchini, J.C., Alves, B.J.R., 2012. Influence of no-tillage and frequency of a green manure legume in crop rotations for balancing $\mathrm{N}$ outputs and preserving soil organic $\mathrm{C}$ stocks. Field Crop Res. 132, 185-195.

Zou, T., Li, T., Zhang, X., Yu, H., Luo, H., 2011. Lead accumulation and tolerance characteristics of Athyrium wardii (Hook.) as a potential phytostabilizer. J. Hazard. Mater. 186, 683-689. 